\title{
Violence against the Brazilian elderlies: an analysis of hospitalizations
}

\author{
Violência contra os idosos brasileiros: uma análise das internações hospitalares \\ Violencia contra los ancianos brasileños: un análisis de las internaciones hospitalarias
}

\section{Vivian Carla de Castro', Leidyani Karina Rissardo', Lígia Carreira'}

\section{'Universidade Estadual de Maringá. Maringá, Paraná, Brazil.
How to cite this article:}

Castro VC, Rissardo LK, Carreira L. Violence against the Brazilian elerdly: na analysis of hospitalizations. Rev Bras Enferm [Internet]. 2018;71(suppl 2):777-85. [Issue Edition: Elerdly Health] DOI: http://dx.doi.org/10.1590/0034-7167-2017-0139

\author{
Submission: 03-22-2017 Approval: 07-22-2017
}

\begin{abstract}
Objective: to identify the prevalence of physical aggression and neglect and abandonment in the hospitalizations of Brazilian elderly people for violence and assault from 2008 to 2013 and the association of these causes with socio-demographic variables related to hospitalization. Method: quantitative, descriptive, cross-sectional study with elderlies hospitalized for assault. Inclusion criteria: to be 60 years old or over, to have been hospitalized in the Unified Health System (SUS) for assault or neglect and abandonment, between 2008 and 2013. The data were collected in February 2016, in Datasus database and descriptive and inferentially, using the Chi-square distribution, in the Epi Info 3.5.4 program. Results: the prevalence of hospitalizations due to assaults and violence prevailed among 60 and 69 years old men in the public sector. For abandonment and neglect, there was a higher prevalence in women, over 80 years old, in the public sector. Conclusion: nurses must be able to identify and prevent violence against the elderly.
\end{abstract}

Descriptors: Elderly; Abuse of the Elderly; Violence; Hospitalization; Geriatric Nursing.

\section{RESUMO}

Objetivo: identificar a prevalência de agressão corporal e negligência e abandono nas internações de idosos brasileiros por agressões no período de 2008 a 2013 e a associação destas causas com variáveis sóciodemográficas e relacionadas à internação. Método: pesquisa quantitativa, descritiva, transversal com idosos internados por agressões. Critérios de inclusão: ter 60 anos ou mais, ter sido hospitalizado no Sistema Único de Saúde por agressão corporal ou negligência e abandono entre 2008 e 2013 . Os dados foram coletados em fevereiro de 2016, na base de dados do Datasus e analisados descritiva e inferencialmente, utilizando-se distribuição Quiquadrado, no programa Epilnfo3.5.4. Resultados: a prevalência das internações por agressão corporal prevaleceu em idosos entre 60 e 69 anos, homens, no setor público. Para negligência e abandono, verificou-se prevalência maior em mulheres, com mais de 80 anos, no setor público. Conclusão: o enfermeiro deve estar capacitado para identificar e prevenir a violência contra o idoso.

Descritores: Idoso; Maus-Tratos ao Idoso; Violência; Hospitalização; Enfermagem Geriátrica.

\section{RESUMEN}

Objetivo: identificar la prevalencia de agresión corporal y negligencia y abandono en las internaciones de ancianos brasileños por agresiones en el período de 2008 a 2013 y la asociación de estas causas con variables sociodemográficas y relacionadas a la internación. Método: investigación cuantitativa, descriptiva, transversal con ancianos hospitalizados por agresiones. Criterios de inclusión: tener 60 años o más, haber sido hospitalizado en el Sistema Único de Salud por agresión corporal o negligencia y abandono, entre 2008 y 2013. Los datos fueron recolectados en febrero de 2016, en la base de datos del Datasus y analizados de forma descriptiva e inferencial, utilizando la distribución Qui-cuadrado, en el programa Epi Info 3.5.4. Resultados: la prevalencia de las internaciones por agresión corporal prevaleció en ancianos entre 60 y 69 años, hombres y en el sector público. Para negligencia y abandono se verificó la prevalencia más grande en mujeres, con más de 80 años y en el sector público. Conclusión: el enfermero debe estar capacitado para identificar y prevenir la violencia contra el anciano.

Descriptores: Ancianos; Maltrato a los Ancianos; Violencia; Hospitalización; Enfermería Geriátrica. 


\section{INTRODUCTION}

The elderly population is experiencing steep growth throughout the world. The elderlies have a higher rate of survival, are gaining visibility and becoming more active and independent, a fact that is mainly due to advances in the health sector ${ }^{(1)}$. However, the burden of physical and cognitive limitations arising from senility and senescence, as well as the intergenerational conflicts that these individuals may experience, increase their vulnerability to social diseases, among which, violence ${ }^{(2)}$.

Although it constitutes a serious public health problem, violence against the elderly population is still a problem hidden from society ${ }^{(1)}$. Violence against the elderlies can be defined as any single or repeated action, or the omission of appropriate action, occurring within a relationship in which there is expectation of trust, which causes injury or distress to an elderly person $^{(3)}$. Violence is believed to result in impairment of the elderly's functional capacity, suicide attempts, violation of human rights, diminished quality of life and high mortality rates ${ }^{(1,3-4)}$.

Violence against the elderlies is often distinguished in five categories. Assault consists in the use of physical force with the intention of causing pain or injury; psychological violence includes verbal or nonverbal actions that generate distress or emotional pain; sexual abuse involves any type of non-consensual sexual activity; financial abuse refers to the exploitation or misappropriation of assets of an elderly person for personal or monetary gain; neglect and abandonment, the most common forms of abuse, relate to the intentional or unintentional failure of the designated caregiver to assume responsibility for the physical and mental health needs of an elderly person ${ }^{(1,5-6)}$.

The current incidence and prevalence of elder abuse are unknown, since such data are underreported ${ }^{(1,4,7-8)}$. It is estimated that there are about 450,000 new cases of violence against people aged 65 and older per year in the United States, with the overall prevalence being estimated at $10 \%$. These numbers are worrying, considering that for each case accounted for, there are five unreported ${ }^{(1,6)}$. In Latin America, the countries with the highest rates of violence are Colombia, Brazil and Panama, respectively, with roughly 102 thousand cases registered each year, of which approximately $37 \%$ are elderly. In Argentina and Chile, this problem is also increasing, since more than 30 thousand elderly people were maltreated in $2009^{(9)}$.

The elderlies are a population group with high vulnerability to abuse, especially when they are single, low educated, have some physical or psychological dependence, and live with children, daughters-in-law and grandchildren ${ }^{(9-11)}$. For these and other reasons, such as shame, intimidation, guilty and fear of retaliation or institutionalization, the elderlies do not report the abuse suffered ${ }^{(4,11-12)}$. This is because, in most cases, the perpetrator is family and lives with the elderly ${ }^{(4)}$.

In Brazil, given the importance of the issue, there has been progress in the implementation of public policies to combat violence against the elderly. This progress began with the promulgation of the Elderly Statute, which made it mandatory to report suspected or confirmed forms of violence by health professionals and the Plan to Combat Elderly Personnel ${ }^{(13)}$.
Regarding health, professionals working in close proximity to the population, especially in nursing, play an important role in the dissemination and discussion of this problem in the community. In addition, the identification of risk situations, based on the close observation of communication, behavior, gestures and facial expressions of the elderlies, will allow the development of appropriate coping strategies. It should be noted that any visit of the elderlies to a health service may be the only opportunity to detect such situations ${ }^{(13)}$.

Violence against the elderlies is a complex phenomenon and difficult to comprehend. Research on the subject has expanded in the international scene since the last decade and has now been more advanced and methodologically more rigorous, contributing with subsidies to tackle the problem ${ }^{(1,6)}$. In general, in the context of the elderly population, studies cover types of abuse, risk factors and notifications ${ }^{(7,11,14)}$, as well as violence related to the domestic and institutional environment ${ }^{(4-5,9)}$ and the approach of the same by health professionals $^{(1-2,5)}$. However, there is still little research that deals with the panorama of hospitalizations due to situations of violence ${ }^{(15)}$.

\section{OBJECTIVE}

To identify the prevalence of assault and neglect and abandonment in the hospitalizations of Brazilian elderly people for assault from 2008 to 2013 and the association of these causes with socio-demographic and hospitalization related variables.

\section{METHOD}

\section{Ethical aspects}

The present study was based on data of public domain, made available electronically by the Ministry of Health and preserving the identity of the subjects, thus dispensing with the appreciation and approval by the Research Ethics Committee.

\section{Study design, place and period}

This was a quantitative, descriptive and cross-sectional study, developed from the information obtained in the Datasus database of the Ministry of Health. Datasus was used as a data collection tool, which contains an information system in health website that can be consulted on the website http://www.datasus.gov.br. The data collection took place during February 2016.

\section{Population or sample; inclusion and exclusion criteria}

The population of the study were the elderlies hospitalized for assault between the years 2008 and 2013, considering Brazil as the geographic unit of analysis. Subjects were selected according to the following inclusion criteria: to be 60 years old or older and to have been admitted to a hospital unit of the Unified Health System (SUS) for assault or neglect and abandonment, from 2008 to 2013.

\section{Study protocol}

The data of hospital admissions were collected in the Hospital Information System (HIS/SUS), whose instrument of registration is the Inpatient Hospital Authorization (IHA), through the Tabnet program. 
According to the International Classification of Diseases (ICD10), assault and neglect and abandonment correspond respectively to codes Y04 and Y06 and are contained in the group of assault, comprised between codes X85 and Y09, which, in turn, chapter XX dealing with external causes of morbidity and mortality.

Tables were generated from the variables selected in the Datasus system, the above-mentioned types of aggression being the dependent variables, and as independent variables: sex; age group; region of Brazil; year of processing; character of service (elective or urgent); and health establishment regime (public or private). For all the independent variables, the "ignored" category was not counted. It should be noted that the variable "character of service" presented six categories in the Datasus. Nevertheless, for this research, only the categories 'urgency' and 'elective' were considered, since it is understood that the others, are different types of accidents (such as injuries and poisonings) and did not involve aggression.

As for the time limit established, the year 2008 marked the launch of the current version of the ICD, which modified not only the classification codes of the cases, but also the data disposition at the base of the Datasus, being necessary to select the previous period or later this year to access the information. As of 2013, it was the most recent year consolidated in the database during the collection period, that is, it included full-time data from January to December, while data for 2014 and 2015 were still subject to change, considering the time information system at national level.

\section{Analysis of results and statistics}

An electronic database was built in the Epi info 3.5.4 program, typed in double entry, to verify data inconsistencies and subsequent confirmation and/or correction based on the original source. The typing was performed by two of the researchers, both with previous experience in managing the Datasus system, with the support of a statistical professional.

A descriptive analysis was carried out for the characterization of the sample and the hospitalizations, as well as the coefficients of prevalence of hospitalization for assault and neglect and abandonment in the studied population. The chi-square distribution was used to verify the differences among hospitalization rates for the causes cited in the different categories of the variables "gender", "age group", "care character" and "health establishment regime". A level of statistical significance of 0.05 was accepted.

The variable "region of Brazil" was excluded from the inferential analysis due to the probable underestimation of hospitalization because of aggression data. However, the variable "year of processing" was not used at this stage, since the comparisons between the two years studied, considering the association test used, would not effectively contribute to the discussion proposal of the present study.

\section{RESULTS}

From 2008 to 2013, 14,651,626 hospitalizations of individuals aged 60 years and over were registered in Brazil. Of these, $930,805(6.3 \%)$ occurred due to external causes, of which 16,814
(1.8\%) reported aggressions assisted as a matter of urgency or elective. In the case of assault and neglect and abandonment, the focus of the present study was represented by 1,787 (10.6\%) and $477(2.8 \%)$ hospitalizations of elderly individuals, respectively.

The hospitalizations due to assault were more frequent among male elderlies (79.7\%), aged 60-69 years $(61.3 \%)$, living in the Southeast Region (45.4\%), assisted at establishments (71.0\%), and in an emergency (93.3\%), with 2013 $(20.8 \%)$ presenting the highest proportion of hospitalizations.

Concerning hospitalizations caused by neglect and abandonment, a higher incidence was observed in male elderlies $(55.3 \%)$, aged 70 to 79 years $(34.8 \%)$, inhabitants of the Southern Region (94.1\%), assisted by public health institutions $(99.1 \%)$ and in an emergency $(67.0 \%)$, with the highest proportion of cases occurring in 2010 (18.6\%). It should be emphasized that the data concerning the Brazilian Regions were excluded from the inferential analysis, since the descriptive analysis showed a possible underestimation of this, considering such a distinction between the absolute frequencies found in the period considered.

Thus, the prevalence of assault in the hospitalizations of the elderlies by aggression was $9.0 \%, 9.2 \%$ and $9.4 \%$, respectively, for the Northeast, Central-West and South Regions, $12.0 \%$ in the Southeast Region and $12.9 \%$ in the Northern Region. Regarding the prevalence of neglect and abandonment, the Northeast Region did not present any notification from 2008 to 2013 and the Central-West Region registered one case $(0.07 \%)$. In the North and Southeast Regions prevalence were $0.5 \%$ and $0.3 \%$, respectively, while in the Southern Region, with $19.8 \%$, it was the highest prevalence of neglect and abandonment in hospitalizations due to aggression.

Regarding the years studied the prevalence of assault (Figure 1) in hospitalizations of the elderly due to aggression ranged from $9.3 \%$ to $12.7 \%$, the lowest being recorded in 2012 and the highest in 2013. Yet the prevalence of neglect and abandonment (Figure 1) were lower and ranged from $2.2 \%$ in 2011 to $4.6 \%$ in 2008 .

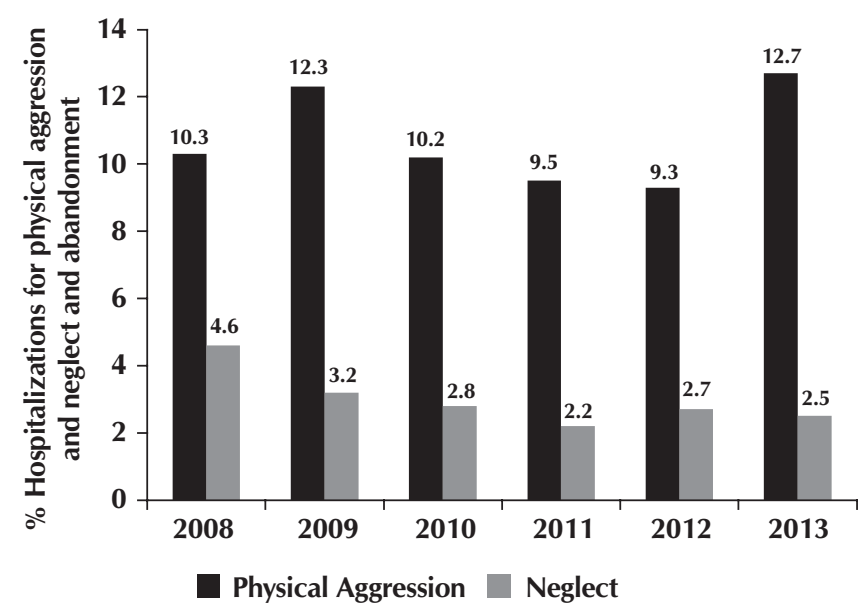

Figure 1 - Prevalence of hospitalization of the elderly due to assault and neglect and abandonment per year, Brazil, 2008-2013 
The distribution of hospitalizations due to assault in the "gender" variable showed a statistically significant difference between the two categories (Table 1), with the male sex being the highest prevalence, $13.6 \%(p<0.001)$, with OR of $2.58(95 \% \mathrm{Cl}, 2.29$ 2.92). Regarding the age group, the prevalence of hospitalization due to assault is inversely proportional to the increase in age. The highest prevalence was found in the $60-69$ age group (14.3\%), with a statistically significant difference between the variables $(p<0.001)$. Considering the age range of 60 to 69 years as reference, both groups from 70 to 79 years and 80 years or older presented OR, which were statistically significant (Table 1).

The prevalence of assault was higher among the emergencies $(10.7 \%)$. However, there was no distinction (Table 1), from the statistical point of view, between categories $(p=0.057)$. The prevalence of assault was higher in hospitalizations in public health institutions, corresponding to $11.5 \%$, with a significant statistical difference between the categories $(p<0.001)$ and OR of $0.76(95 \% \mathrm{Cl}, 0.68-0,85)$, indicating that hospitalization in private establishments is a protective factor for assault (Table 1).

Regarding the prevalence of neglect and abandonment in the hospitalizations of elderly due to assault, it was verified higher prevalence among women (3.4\%), with a statistically significant difference between genders $(p=0,001)$, with an OR of $0,74(\mathrm{Cl} 95 \% ; 0.61-0.89)$, suggesting that being a man is a protection factor for neglect and abandonment (Table 2).

Regarding the age bracket, the highest prevalence of hospitalization due to neglect and abandonment occurred in the category superior to 80 years old, having a directly proportional relation, that is, the prevalence increased as the age advanced. The association between the variables showed a statistically significant difference $(p<0.001)$ among the categories. Considering the category of 80 years old or older, the ranges of 60 to 69 and 70 to 79 years were indicated as protection factors, according to the statistically significant ORs presented (Table 2).

Table 1 - Distribution of elderly hospitalizations due to assault, according to different variables, Brazil, 2008-2013

\begin{tabular}{|c|c|c|c|c|c|}
\hline \multirow[b]{2}{*}{ Variables } & \multicolumn{2}{|c|}{ Hospitalizations } & \multirow[b]{2}{*}{$p$ value } & \multirow[b]{2}{*}{ OR } & \multirow[b]{2}{*}{$\mathrm{Cl}_{95 \%}(\mathrm{OR})$} \\
\hline & $\begin{array}{c}\text { Aggressions } \\
\mathbf{n}\end{array}$ & $\begin{array}{c}\text { Body aggression } \\
\text { n (\%) }\end{array}$ & & & \\
\hline \multicolumn{6}{|l|}{ Gender } \\
\hline Male & 10,501 & $1.425(13.6 \%)$ & $<0.001^{*}$ & 2.58 & $2.29-2.92$ \\
\hline Female & 6,313 & $362(5.7 \%)$ & & 1.00 & - \\
\hline \multicolumn{6}{|l|}{ Age bracket } \\
\hline 60-69 years & 8,774 & $1096(14.3 \%)$ & $<0.001 *$ & 1.00 & - \\
\hline $70-79$ years & 4,946 & $486(9.8 \%)$ & & 0.76 & $0.68-0.86$ \\
\hline$\geq 80$ years & 3,094 & $205(6.6 \%)$ & & 0.50 & $0.42-0.58$ \\
\hline \multicolumn{6}{|l|}{ Attendance profile } \\
\hline Urgency & 15,503 & $1.668(10.7 \%)$ & 0.057 & 1.00 & - \\
\hline Elective & 1,311 & $119(9.0 \%)$ & & 0.83 & $0.68-1.01$ \\
\hline \multicolumn{6}{|c|}{ Health establishment regimen } \\
\hline Public & 11,070 & $1.270(11.5 \%)$ & $<0.001^{*}$ & 1.00 & - \\
\hline Private & 5,744 & $517(9.0 \%)$ & & 0.76 & $0.68-0.85$ \\
\hline
\end{tabular}

Note: ${ }^{*}$ Value of $p<0.05-$ Chi-square test

Table 2 - Distribution of elderly hospitalizations due to neglect and abandonment, according to different variables, Brazil, 2008-2013

\begin{tabular}{|c|c|c|c|c|c|}
\hline \multirow[b]{2}{*}{ Variables } & \multicolumn{2}{|c|}{ Hospitalizations } & \multirow[b]{2}{*}{$p$ value } & \multirow[b]{2}{*}{ OR } & \multirow[b]{2}{*}{$\mathrm{Cl}_{95 \%}(\mathrm{OR})$} \\
\hline & $\begin{array}{c}\text { Aggressions } \\
\mathbf{n}\end{array}$ & $\begin{array}{c}\text { Neglect and neglect } \\
\text { n (\%) }\end{array}$ & & & \\
\hline \multicolumn{6}{|l|}{ Gender } \\
\hline Male & 10,501 & $264(2.5 \%)$ & $0.001^{*}$ & 0.74 & $0.61-0.89$ \\
\hline Female & 6,313 & $213(3.4 \%)$ & & 1.00 & - \\
\hline \multicolumn{6}{|l|}{ Age bracket } \\
\hline 60-69 years & 8,774 & $162(1.9 \%)$ & $<0.001 *$ & 0.37 & $0.29-0.47$ \\
\hline $70-79$ years & 4,946 & $166(3.3 \%)$ & & 0.69 & $0.54-0.87$ \\
\hline$\geq 80$ years & 3,094 & $149(4.8 \%)$ & & 1.00 & - \\
\hline \multicolumn{6}{|l|}{ Attendance profile } \\
\hline Urgency & 15,503 & $320(2.0 \%)$ & $<0.001 *$ & 1.00 & - \\
\hline Elective & 1,311 & $157(12.0 \%)$ & & 6.46 & $5.26-7.92$ \\
\hline \multicolumn{6}{|c|}{ Health establishment regimen } \\
\hline Public & 11,070 & $473(4.3 \%)$ & $<0.001^{*}$ & 1.00 & - \\
\hline Private & 5,744 & $4(0.07 \%)$ & & 0.02 & $0.00-0.04$ \\
\hline
\end{tabular}

Note: *Value of $p<0.05-$ Chi-square test 
The prevalence of neglect and abandonment, in relation to the nature of care, stood out in the elective $(12.0 \%)$, with a distinction (Table 2) from the statistical point of view, between the categories $(p<0.001)$, being the OR of $6.46(95 \% \mathrm{Cl}, 5.26$ 7.92). Regarding the health care system, the prevalence of neglect and abandonment was higher in hospitalizations in public institutions, corresponding to $4.3 \%$ (Table 2), also with a statistically significant difference between the variables $(p<0.001)$, with OR of $0.02(95 \% \mathrm{Cl}, 0.00-0.04)$, denoting hospitalization in a private establishment as a protection factor.

\section{DISCUSSION}

Violence is a public health problem in Brazil, given it has a major impact on the health and social security systems, as well as on the public security sector, affecting negatively the quality of life of people. The results of the present study demonstrated that the external causes, that is, the violence and the accidents, corresponded to $6.3 \%$ of the causes of hospitalization among the Brazilian elderlies in the considered period. They are thus the sixth cause of hospitalization in the country and the third cause of mortality in the general population ${ }^{(16)}$.

The vast majority of research on external causes is supported by official current registry sources, through the Hospital Information System (HIS), as in the case of this study and the Brazil Mortality Information System (MIS) ${ }^{(17)}$. Currently, the HIS/SUS represents an important source of data for the knowledge of epidemiological profile of hospital admissions and has been applied in several gerontology studies, presenting a high level of acceptance by the scientific community ${ }^{(18)}$. Although there is evidence of an association between violence against the elderly and an increase in the rate of hospitalization $^{(15)}$, the investigations in this area are scarce ${ }^{(19)}$.

Assault hospitalizations accounted for $10.6 \%$ of hospitalizations due to aggression to the elderlies. Assaults encompass any injury, assault or threaten with a weapon, or inappropriate restraint of an elderly person by a caretaker or other person in a position of trust ${ }^{(7)}$. There are various forms of assault, such as tapping and striking objects and physical or chemical restrictions by means of psychoactive drugs, the most commonly cited forms ${ }^{(7-8)}$.

The signs and symptoms of assault consist in the observation of abrasions, lacerations, bruises, fractures, burns, pain, depression and behavioral problems ${ }^{(6)}$. Early identification of signs, symptoms and patterns of violence-related injuries should be a concern of health professionals, although it is not easy to precisely distinguish situations of violence from those that are accidental or pathological ${ }^{(19)}$.

The proportion of hospitalizations due to neglect and abandonment among admissions due to aggression was $2.8 \%$. It is one of the most common forms of violence against the elderlies, although it is the least denounced because it comprises, in essence, a group with physiological and functional alterations ${ }^{(20-21)}$. A population-based study conducted in the United States showed an association between negligence and an increase in the hospitalization rate, and the elderlies, victims of this type of abuse, were twice as likely to be hospitalized ${ }^{(15)}$.
Negligence can be differentiated into passive, unintentional, and intentional. Actions such as neglecting vital needs, allowing malnutrition, dehydration and ulcer formation in the elderly and not carrying out safety precautions are forms of passive neglect. On the other hand, active neglect occurs when the aggressor intimidates and insults the elderly; ignores an emergency situation; leaves the dependent elderly person alone for an inadequate amount of time; deprives the elderly of food and important treatments ${ }^{(14)}$.

As for hospitalizations due to assault, a higher prevalence was observed in the North and Southeast Regions. Regarding the hospitalizations due to neglect and abandonment, the South Region presented a higher prevalence, although a significant discrepancy was observed in the other regions. This issue may be related to the underreporting of cases, whether due to professionals' limitations in identifying signs of violence ${ }^{(2)}$, or the lack of reporting by elderly people who often feel shame, intimidation and fear ${ }^{(4,11-12)}$. It was also considered that Brazil is a country with continental dimensions, with wide regional inequalities, in the demographic, economic, social, cultural and health conditions ${ }^{(22)}$.

Concerning the years that studied the prevalence of hospitalizations for assault against the elderly population it was observed that, in 2013, after a decreasing period between 2009 and 2012, and a higher prevalence of hospitalizations due to neglect and abandonment in 2008, followed by drops there was new increase in 2012. This profile can be related to the advent of the Plan of Action to Combat Violence against the Elderly, whose objective was to promote organized, monitored and evaluated initiatives at all stages to confront all forms of violence against the elderly ${ }^{(13)}$.

The Plan focused on the 2007-2010 period, when hospitalizations for these two types of aggression appeared to reach lower prevalence. Nevertheless, prevalence increased again after this period, allowing the reflection that actions to combat violence are still presented by sporadic initiatives, with subsequent moments of apathy by national and international organizations, researchers and the public in general ${ }^{(11)}$.

Based on the inferential analysis, it was possible to conclude that the male gender and the younger age group (60 to 69 years old) were the ones that most interned due to assault, whereas in the neglect and abandonment hospitalizations, women and the elderly over 80 years. A multilevel study conducted in seven European countries corroborates the data highlighted in this study, emphasizing the prevalence of assault to elderly men and other types of aggression to elderly women $^{(23)}$. Although they live longer, women experience a greater period of physical impairment before death than men, contributing to cases of neglect and abandonment ${ }^{(20,24)}$.

It is believed that assault is reproduced mainly by financial difficulties, by shock of generations and problems in physical spaces, hence the association between this type of aggression and the hospitalizations of younger people. On the other hand, abandonment and neglect, despite being also directly associated with such factors, the prevalence of occurrence is related to the degree of dependence of the elderly ${ }^{(7,25)}$ and, therefore, is associated with hospitalizations of older people. This result 
corroborates a survey on neglect performed with the elderly of a home care program whose average age was 84.8 years ${ }^{(20)}$.

The most vulnerable group to neglect and abandonment has been the least addressed by public health policies. The emphasis that the National Programme for Health Care of the Elderly offers for autonomy and independence hides an important piece of national and international literature that is the dependent, deprived elderly person with a lack of access to health services as the main victim of violence ${ }^{(26)}$. The limitation of government support and of society to the families of dependent elderly people becomes one of the conditions for the genesis of violence, forming a process of structural violence.

The political structure strongly influences the socialization and care practices of dependent elderly families, since the majority depends on the public health system. In the present study, the prevalence of hospitalizations of the elderly by the two types of aggression studied was statistically higher in public health establishments. The Brazilian health system is a complex network of services, made up of the public sector, financed by the State; the private sector, maintained with public or private resources and by the supplementary health sector, with various types of private health plans. These components are interconnected, and the population can use the services of all, depending on the access or financial resources available to them. It is known, however, that private health insurance plans primarily serve a younger and healthier population ${ }^{(22)}$.

A survey conducted by the Violence and Accident Surveillance System survey in the city of Campinas, Brazil, found that almost $70 \%$ of emergency care due to violence and accidents was financed by the public sector. Aggression and abuse were twice as frequent in public versus private units. These findings suggest that public services are more used in a situation of greater severity, either because serious injuries reach the population dependent on the SUS, the principle of universality or the provision of qualified assistance and specialized resources for these cases by the public sector ${ }^{(17)}$.

The urgency for hospitalizations by the elderlies due to assault represented a higher prevalence $(10.7 \%)$ in the results of this study. Even though, there was no statistically significant difference between the urgency and elective categories. Regarding the hospitalizations due to neglect and abandonment, the inferential analysis pointed out that the elective category had a significant prevalence. This is due to the occurrence of fractures, bruises, burns or other physical injuries considered to be acute trauma, which lead the individual to seek emergency care ${ }^{(23,25)}$.

Despite the greater diffusion of data on mortality, it is worth noting that for each death due to injuries, there are 30 hospitalized victims. This data points out the relevance of investigations about the health network that specifically assesses these diseases, especially in the elderly population that has particularities, such as the small functional reserve and the reduced capacity to respond to the increased physiological demands imposed by situations of violence. Health services, in turn, are fundamental in the identification, therapy and rehabilitation of the elderly victims of violence. However, there are still few professionals sensible and qualified to perform a careful listening, as well as the notification and appropriate referral of the identified $\operatorname{cases}^{(27-28)}$.
It is believed that the consolidation of the professional quality to identify the signs of violence against the elderly person comes primarily from investment in health policies ${ }^{(29)}$. Researchers highlight that, among the national health policies for the elderly population, the most objective and assertive document on violence is the Statute of the Elderly (Estatuto do Idoso) $)^{(26,30)}$. Violence is emphasized in the communication process, in the case of suspected or confirmed abuse, by health professionals to the police authority, the Public Ministry, and the Municipal, State and National Councils of the elderly ${ }^{(30)}$. As of 2011, this communication has also been occurring through the requirement of compulsory notification, by public and private health services, to the sanitary authority(31).

The commitment of management and health professionals to stay up to date and trained on the issue of violence against the elderlies is extremely relevant for the early detection of violence and aggression cases. National(21,28) and international studies ${ }^{(1,8)}$ show that the elderlies constitute a group vulnerable to violence, a phenomenon whose existence is broadly independent of socioeconomic conditions, status and culture. However, it is considered that the life-course perspective provides a useful framework for understanding the elderly in terms of violence, and the history of child abuse may have an influence on abuse and what happens later in life of the individual ${ }^{(29)}$.

Certain characteristics of both the elderly and the potential abuser increase the propensity to cases of assault and violence. Among the elderlies, risk factors are: being female, having cognitive limitations, sharing the residence with other relatives, not having a social support network and fragility. As for aggressors: belong to the male sex, be over 40 years old, present a family history of abusive behavior, be a son or a spouse of the victim, have mental health problems, make abusive use of chemical substances ${ }^{(8,14,28)}$.

Keeping sentinel over these cases and participating in an articulated and interdisciplinary way with other social sectors can guarantee patient safety, as well as favor prevention and coping with this social problem ${ }^{(7,12,19)}$. It should be emphasized that nurses enrolled in Primary Care have a privileged position in this sense, given their rapprochement with the community. Nonetheless, those who work in emergency services should take the chance of every opportunity to care for the elderly to investigate situations of violence ${ }^{(12,19)}$.

\section{Limitations of the study}

The present research presents some limitations, mainly regarding the use of secondary data with the database of hospital admissions, the HIS-SUS. Attention must be paid to the union of diagnoses registered in the HIS-SUS database, since there is no possibility of analyzing each particular variable, such as the union of the variables "neglect" and "abandonment". In addition, the data recorded differed between the regions and the time series analyzed. This variation may be a result of both the difficulty of completing the information in the IHA and the underreporting of facts. As previously mentioned, the data for the Brazilian Regions were excluded from the inferential analysis, given that the descriptive analysis showed a possible underestimation of them, considering such a distinction between absolute frequencies. 
Even with these considerations regarding some limitations of the use of secondary data and the Information Systems of SUS, it is important to encourage the use of this information and health professionals to correctly fill out the documents that feed the health systems. Professional qualification is essential, since SUS databases are a source recommended by the Ministry of Health to follow the health indicators of the elderlies, important for planning health initiatives.

\section{Contributions to the area of nursing and public health}

The present study presents an overview of the hospitalizations of the elderlies due to assault, neglect and abandonment in Brazil. The results are intended to alert, based on reliable data, health professionals as well as relevant authorities on the magnitude of this growing social problem in the present day which is violence against the elderlies.

Despite the efforts and the visible expansion of the body of scientific knowledge related to the theme, since it is a veiled theme in society, a deeper understanding of the cause is needed. Influencing factors and consequences of this process for the elderlies and for the community are enormous. Thus, with a focus on hospitalizations, this study points out that, for each case accounted at a hospital unit, there are thousands more camouflaged in the domestic and institutional environment, which encourages further research based on the gaps identified here.

Therefore, health professionals, especially nurses, due to their close proximity to the public served, should take the chance of every opportunity to investigate situations of violence in the elderlies who seek the health service, either in the Basic Health Unit or in the emergency and emergency doors. From this, they should use strategies to identify and address the problem, using validated instruments, group dynamics, or even attentive listening during the nursing consultation, as well as acting as disseminators of information related to violence.

\section{CONCLUSION}

The present study had as objective to verify the prevalence of physical aggression and neglect and abandonment among hospitalizations for aggressions of Brazilian elderly people between 2008 and 2013, and the association between these causes of hospitalization and other variables. It was observed that the highest prevalence of hospitalizations of the elderly due to assault and neglect and abandonment occurred in the North and South Regions, respectively. Regarding the years that studied the prevalence of physical aggression in the hospitalizations of the elderlies by aggression rates were between $9.3 \%$ and $12.7 \%$, the lowest recorded in 2012 and the highest in 2013. The prevalence of neglect and abandonment varied between $2.2 \%$ in 2011 and $4.6 \%$ in 2008 .

The prevalence of hospitalizations due to assault among the hospitalizations of elderly people due to aggression was statistically higher for men aged 60 to 69 in public health institutions. Regarding the prevalence of neglect and abandonment in the hospitalizations of elderly people due to aggression, there was a significantly higher prevalence among women, over 80 years of age, in an elective setting in public health establishments.

The findings of this research converge in subsidies relevant to the theme, mainly because they are hospitalizations of elderly people due to violence, a common situation in health and nursing practice, but still little explored in the national and international scenario. The elderly public deserves special attention because of its known vulnerability and, in addition, the damage that violence, as a serious public health problem, causes in the quality of life of the senile, as well as for the whole society. Hence, this investigation foments new questions about the subject, provides information for the planning of health initiatives and constitutes a tool for the strengthening of public policies to combat violence against the elderly.

\section{REFERENCES}

1. Bond $\mathrm{MC}$, Butler $\mathrm{KH}$. Elder abuse and neglect: definitions, epidemiology, and approaches to emergency department screening. Clin Geriatr Med [Internet]. 2013[cited 2017 Mar 20];29:257-73. Available from: https://www.ncbi.nlm.nih.gov/pubmed/23177610

2. Wanderbroocke ACNS, Moré CLOO. Abordagem profissional da violência familiar contra o idoso em uma unidade básica de saúde. Cad Saúde Pública [Internet]. 2013[cited 2017 Mar 20];29(12):2513-2. Available from: http://www.scielo.br/pdf/csp/ v29n12/v29n12a15.pdf

3. World Health Organization. WHO. The Toronto declaration on the global prevention of elder abuse [Internet]. Geneva: WHO; 2002. [cited 2015 Jan 16]. Available from: http://www.who.int/ageing/publications/toronto declaration/en/

4. Castle N, Ferguson-Rome JC, Teresi JA. Elder Abuse in Residential Long-Term Care: an update to the 2003 National Research Council Report. J Appl Gerontol [Internet]. 2015[cited 2017 Mar 20];34(4):407-43. Available from: https://www.ncbi.nlm.nih.gov/ pubmed/24652890

5. Powers JS. Common presentations of elder abuse in health care settings. Clin Geriatr Med [Internet]. 2014 [cited 2017 Mar 20];30:729-41. Available from: http://www.geriatric.theclinics.com/article/S0749-0690(14)00074-3/fulltext

6. Lachs MS, Pillemer KA. Elder abuse. N Engl J Med [Internet]. 2015[cited 2017 Mar 20];373:1947-56. Available from: http://www. nejm.org/doi/pdf/10.1056/NEJMra1404688

7. Young LM. Elder physical abuse. Clin Geriatr Med [Internet]. 2014[cited 2017 Mar 20];30:761-8. Available from: http://www. geriatric.theclinics.com/article/S0749-0690(14)00075-5/fulltext 
8. Burnett J, Achenbaum WA, Murphy KP. Prevention and early identification of elder abuse. Clin Geriatr Med[Internet]. 2014[cited 2017 Mar 20];30:743-59. Available from: http://www.geriatric.theclinics.com/article/S0749-0690(14)00083-4/fulltext

9. Pina GVE, Rodríguez JP, Cancino AD, Enamorado JER. Violencia intrafamiliar contra el adulto mayor en una comunidad de Guinea Bissau. MEDISAN [Internet]. 2013[cited 2017 Mar 20];17(7):1053. Available from: http://scielo.sld.cu/pdf/san/v17n7/ san04177.pdf

10. Naughton C, Drennan J, Lyons I, Lafferty A. The relationship between older people's awareness of the term elder abuse and actual experiences of elder abuse. Int Psychogeriatr [Internet]. 2013[cited 2017 Mar 20];25(8):1257-66. Available from: https://doi. org/10.1017/S1041610213000513

11. Garbin CAS, Joaquim RC, Rovida TAS, Garbin AJI. Elderly victims of abuse: a five year document analysis. Rev Bras Geriatr Gerontol [Internet]. 2016[cited 2017 Mar 20];19(1):87-94. Available from: http://www.scielo.br/pdf/rbgg/v19n1/1809-9823rbgg-19-01-00087.pdf

12. Oliveira AAV, Trigueiro DRSG, Fernandes MGM, Silva AO. Maus-tratos a idosos: revisão integrativa da literatura. Rev Bras Enferm [Internet]. 2013[cited 2017 Mar 20];66(1):128-33. Available from: http://www.scielo.br/pdf/reben/v66n1/v66n1a20.pdf

13. Camacho ACLF, Alves RR. Mistreatment against the elderly in the nursing perspective: an integrative review. J Nurs UFPE [Internet]. 2015[cited 2017 Mar 20];9(supl.2):927-35. Available from: https://periodicos.ufpe.br/revistas/revistaenfermagem/ article/download/10418/11201

14. Lacher S, Wettsteinb A, Senna O, Rosemanna T, Hasler S. Types of abuse and risk factors associated with elder abuse. Swiss Med Wkly [Internet]. 2016[cited 2017 Mar 20];146:w14273. Available from: https://smw.ch/article/doi/smw.2016.14273

15. Dong X, Simon MA. Elder Abuse as a Risk Factor for Hospitalization in Older Persons. JAMA Intern Med [Internet]. 2013[cited 2017 Mar 20];173(10):911-17. Available from: https://jamanetwork.com/journals/jamainternalmedicine/fullarticle/1675876

16. Reichenheim ME, Souza ER, Moraes CL, Jorge MHPM, Silva CMFP, Minayo MCS. Violence and injuries in Brazil: the effect, progress made, and challenges ahead. Lancet[Internet]. 2011[cited 2017 Mar 20];6736(11):75-89. Available from: http://www. thelancet.com/pdfs/journals/lancet/PIIS0140-6736(11)60053-6.pdf

17. Belon AP, Silveira NYJ, Barros MBA, Baldo C, Silva MMA. Atendimentos de emergência a vítimas de violências e acidentes: diferenças no perfil epidemiológico entre o setor público e o privado. VIVA - Campinas/SP, 2009. Ciênc Saúde Colet [Internet]. 2012[cited 2017 Mar 20];17(9):2279-90. Available from: http://www.scielo.br/pdf/csc/v17n9/a10v17n9.pdf

18. Castro VC, Borghi AC, Mariano PP, Fernandes CAM, Mathias TAF, Carreira L. Perfil de internações hospitalares de idosos no âmbito do sistema único de saúde. Rev Rene [Internet]. 2013[cited 2017 Mar 20];14(4):791-800. Available from: http://www. revistarene.ufc.br/revista/index.php/revista/article/viewFile/1269/pdf

19. Paiva MM, Tavares DMS. Physical and psychological violence against the elderly: prevalence and associated factors. Rev Bras Enferm [Internet]. 2015[cited 2017 Mar 20];68(6):1035-41. Available from: http://www.scielo.br/pdf/reben/v68n6/en_0034-7167reben-68-06-1035.pdf

20. Queiroz ZPV, Lemos NFD, Ramos LR. Fatores potencialmente associados à negligência doméstica entre idosos atendidos em programa de assistência domiciliar. Ciênc Saúde Colet [Internet]. 2010[cited 2017 Mar 20];15(6):2815-24. Available from: http:// www.scielo.br/pdf/csc/v15n6/a19v15n6.pdf

21. Castro AP, Guilam MCR, Sousa ESS, Marcondes WB. Violência na velhice: abordagens em periódicos nacionais indexados. Ciênc Saúde Colet [Internet]. 2013[cited 2017 Mar 20];18(5):1283-1292. Available from: http://www.scielo.br/pdf/csc/v18n5/13.pdf

22. Paim J, Travassos C, Almeida C, Bahia L, Macinko J. The Brazilian health system: history, advances, and challenges. Lancet [Internet]. 2011[cited 2017 Mar 20];377(9779):1778-97. Available from: http://actbr.org.br/uploads/conteudo/925_brazil1.pdf

23. Fraga S, Lindert J, Barros H, Torres-González F, loannidi-Kapolou E, Melchiorre MG, et al. Elder abuse and socioeconomic inequalities: a multilevel study in 7 European countries. Prev Med [Internet]. 2014[cited 2017 Mar 20];61:42-47. Available from: https://www.ncbi.nlm.nih.gov/pubmed/24440160

24. Pinto FNFR, Barham EJ, Albuquerque PP. Idosos vítimas de violência: fatores sóciodemográficos e subsídios para futuras intervenções. Rev Est Pesq Psicol [Internet]. 2013[cited 2017 Mar 20];13(3). Available from: http://www.e-publicacoes.uerj.br/ index.php/revispsi/article/view/8610

25. Pillemer K, Burnes D, Riffin C, Lachs MS. Elder abuse: global situation, risk factors, and prevention strategies. Gerontol [Internet]. 2016[cited 2017 Mar 20];56(S2):194-205. Available from: https://doi.org/10.1093/geront/gnw004

26. Souza ER, Minayo MCS. Inserção do tema violência contra a pessoa idosa nas políticas públicas de atenção à saúde no Brasil. Ciênc Saúde Colet [Internet]. 2010[cited 2017 Mar 20];15(6):2659-68. Available from: http://www.scielo.br/pdf/csc/v15n6/ a02v15n6.pdf

27. Lima MLC, Souza ER, Acioli RML, Bezerra ED. Análise dos serviços hospitalares clínicos aos idosos vítimas de acidentes e violências. Ciênc Saúde Colet [Internet]. 2010[cited 2017 Mar 20];15(6):2687-97. Available from: http://www.scielo.br/pdf/csc/ v15n6/a07v15n6.pdf

28. Mascarenhas MDM, Andrade SSCA, Neves ACM, Pedrosa AAG, Silva MMA, Malta DC. Violência contra a pessoa idosa: análise das notificações realizadas no setor saúde - Brasil, 2010. Ciênc Saúde Colet [Internet]. 2012[cited 2017 Mar 20];17(9):2331-41. Available from: http://www.scielo.br/pdf/csc/v17n9/a14v17n9.pdf 
29. McDonald L, Thomas C. Elder abuse through a life course lens. Int Psychogeriatr [Internet]. 2013[cited 2017 Mar 20];25(8):123543. Available from: https://doi.org/10.1017/S104161021300015X

30. Brasil. Lei $\mathrm{n}^{\circ}$. 10.741, de $1^{\circ}$ de outubro de 2003. Dispõe sobre o Estatuto do Idoso e dá outras providências. Diário Oficial da União 3 out 2003.

31. Brasil. Lei $n^{\circ} .12 .461$, de 26 de julho de 2011. Altera a Lei $n^{\circ} 10.741$, de $1^{\circ}$ de outubro de 2003, para estabelecer a notificação compulsória dos atos de violência praticados contra o idoso atendido em serviço de saúde. Diário Oficial da União 27 jul 2011. 